\title{
Determinant of Sesame Export Performance in Ethiopia: A Panel Gravity Model Application
}

\begin{tabular}{|c|c|}
\hline \multicolumn{2}{|c|}{$\begin{array}{l}\text { Murad Mohammed Baker }{ }^{\mathbf{1 , a}, *} \text {, Beyan Ahmed Yuya }{ }^{\mathbf{2}, \mathbf{b}} \\
{ }^{1} \text { Department of Statistics, Haramaya University. P.O.box } 138 \text { Dire Dawa, Ethiopia } \\
{ }^{2} \text { School of Agricultural Economics and Agribusiness, Haramaya University. P.O.box } 138 \text { Dire Dawa, Ethiopia } \\
{ }^{*} \text { Corresponding author }\end{array}$} \\
\hline A R T I C LE I N F O & A B S T R A C T \\
\hline $\begin{array}{l}\text { Keywords: } \\
\text { Sesame exports } \\
\text { Ethiopia } \\
\text { Gravity model } \\
\text { Fixed effect model } \\
\text { Random effect model }\end{array}$ & $\begin{array}{l}\text { Ethiopia's sesame export earn percentage share in the total export had been rapid declining over the } \\
\text { last decades while it was the second commodity in currency grossing of the country. The objective } \\
\text { of this study was to examine the determinant factors of Ethiopia's sesame exports performance, in } \\
\text { the aspect of export trade, by the use of a more realistic model approach, a panel gravity model. It } \\
\text { used short panel data that cover } 11 \text { countries of consistent Ethiopia's sesame importers for the period } \\
\text { of } 13 \text { years from } 2002 \text { to } 2014 \text {. The panel unit root test of Levin-Lin-Chu was used for each variable } \\
\text { and applied the first difference transformation for the variables that had a unit root. The random } \\
\text { effect model results suggested that real gross domestic product of importing countries; Ethiopian } \\
\text { real gross domestic product, real exchange rate and weighted distance were found to be the } \\
\text { determinant factors of Ethiopia's sesame exports performance. The estimated results revealed that } \\
\text { as real gross domestic product of importing countries increase by } 1 \% \text {, the flows of Ethiopia's sesame } \\
\text { exports performance increase by } 1.63 \% \text {. Based on the finding results, the researcher recommends } \\
\text { that the policy maker must adopt the policies that reduce the cost of shipping through improving the } \\
\text { infrastructure for shipments sector and contract a free trade agreement with distant countries. The } \\
\text { government should encourage the private sector to diversify their products and improving the quality } \\
\text { of its products to increase the competitiveness the Ethiopian products in foreign markets. }\end{array}$ \\
\hline
\end{tabular}

\section{Introduction}

Ethiopia's export sector has been making different measures of strategies to the improvement of the export performance. In the last three decades mainly, the Transitional Government of Ethiopia (TGE) has undertaken liberalization and structural modification program to address the imbalance of the economy along with the International Monetary Fund (IMF) and World Bank. The economic policy of Transitional Government of Ethiopia (TGE) recognized the importance of rising and diversifying the country's export to comfort shortages of exchange along with a free market based economic agent by different trade strategies, policies and trade liberalization procedures (Wondesen and Fekadu, 2019).

According to UNCTAD (2017), Ethiopia's commodity exports share out of its total trade in value was $92 \%$ during the year 2014/15. This composes the country among the most commodity export based countries in the world. UNCTAD makes a country as strongly commodity export dependent when a country's commodity exports value is more than $80 \%$ of its total trade in exports value. Thus, the sustainability of currently on faster growing economy of Ethiopia also hinges on confronting this particular challenge and risk of commodity dependence, among others.

The export sector of Ethiopia is structurally contingent on mainly agricultural commodities. Coffee, oilseeds, hides and skins have long been the major manifestations of the sector. Through time, as new items such as khat, cut flowers and electricity coupled the country's export range, the relative share and control of these major exports have declined, despite the fact that their trade quantities have been increasing in absolute terms (World bank, 2014). Ethiopian Commodity Exchange (ECX) sector was executed the export of some of the agricultural commodities. Currently, six agricultural commodities, specifically coffee, sesame seed, haricot bean, maize, wheat and mung bean are traded at the Exchange. The former three commodities' export trading in the country is only allowed through the Exchange on regular trading days, whereas the later three commodities are traded at both the Exchange and the customary markets (ATA, 2017). 
Ethiopia experienced double digit economic growth, averaging $10.8 \%$ since 2005 , which has mainly been underpinned by public sector led development. Real gross domestic product (GDP) is estimated to have grown by $10.2 \%$ in fiscal year 2014/15 (Wondifraw et al., 2016). During the last three years, that is 2014/15 - 2016/17, average annual export value of the country was approximately 3 billion USD, of which the top export commodities' shares were coffee $(27.1 \%)$, oilseeds $(15.2 \%)$, gold $(9.3 \%)$, khat $(9.2 \%)$, pulses $(8.3 \%)$ and cut flowers (7.4\%). Moreover, breakdown of the oilseed exports indicate that sesame seed has significantly dominated the subgroup (Addis A. 2018). During the same period, the average annual export value of sesame seed was more than 400 million USD. This is concerning $10 \%$ of the country's total export value or more than $90 \%$ of the total oilseeds export value. Niger seed, castor seed and linseed in this order are the next top export oilseeds (ERCA, 2017; NBE, 2017).

According to International Trade Centre (ITC), sesame exports have increased on average by about $20 \%$ from 2006 to 2015. On average from 2006 to 2015, the major five sesame seed exporters (suppliers) of the world are India, Nigeria, Ethiopia, Sudan and United Republic of Tanzania with a world share of $20.57 \%, 16.37 \%, 16 \%$, $8.96 \%$ and $4.06 \%$, respectively. In Ethiopia, sesame seed is the second most important agricultural commodity after coffee in foreign exchange earnings (FAO, 2014). Among the oilseed commodity groups, the contribution of sesame has been more than $61 \%$ on average, the remaining export produce include nigger seed, linseed, groundnuts, rape seed and caster-oil taking up the remaining 39\% of oilseed export value. Recently, sesame export brought half a billion dollars into the Ethiopian economy in 2015/16 fiscal year (Naoh, 2018).

As the majority of the African countries total exports which is more than $80 \%$ are essential commodities and the long term turn down in prices, the instability of commodity markets, weakening in terms of trade and variability of export capacity are said to be main factors that affect export performance and hamper economic growth in Africa (UNCTAD, 2008). Ethiopia's export performance is also affected by the real exchange rate, the distance between Ethiopia and its importing countries, supply side factors: real gross domestic product, population, average institutional quality, domestic inflation and trade policy, and demand side factors: population, openness to trade and real gross domestic product (Eyayu, 2014). The importance of studying the determinants of sesame export is relevant to the importance of sesame export in achieving economic development in outlook of the fact that sesame is the second export commodity next to coffee in Ethiopia. Therefore, the objective of this study was to identify major determinant factors of supply-side and demand-side factors of the Ethiopia's sesame export performance.

\section{Material and Methods}

\section{Data Source and Variables}

This study was employed annual panel data of Ethiopia's Sesame Export and its trading partners of 11 countries such as Canada, China, Egypt, Greece, Israel, Jordan, Netherland, Saudi Arabia, Turkey, United State of
America, and Yemen over the period of 2002-2014. The use of panel data helps to confine the significant relationships among variables over time, improve efficiency of econometric estimates and offer more variability, more degree of freedom and reduce the correlation among explanatory variables, improve the reliability of the regression results and controls for unobservable individual heterogeneity (Baltagi, 2005).If individual effects were correlated with the explanatory variables, OLS estimates omitting individual effects were biased. Therefore, this study employed panel data estimation for the empirical gravity model of trade.

The dependent variable used in the analysis was the sesame export in US dollars from Ethiopia to its trading partners. The data on sesame exports were generated from the FAOSTAT databases. The data on GDP in US dollar was obtained from the World Development Indicators (WDI)databases of the World Bank. Data on population was obtained from the World Development Indicators databases of the World Bank. Data on domestic inflation was extracted from WDI databases of World Bank. Data on real exchange rate was obtained from International Monetary Fund (IMF) database. Distance in kilometers was obtained from FAOSTAT databases.

\section{Theoretical Frame of Gravity Model}

The trade gravity model was the econometric model that often use for ex-post analyses of international trade flows as a baseline model for estimating the impact of a variety of policy issues. It was based on the idea that overall trade volumes between the two nations depend on the size of the two nations and the distance they are apart. The gravity model was first developed following the physics gravity model derived by Newton in 1687 (Newton, 1687) and was then used by economists in the 1960s to analyze international trade flows, such as, Linder (1961), Tinbergen (1962) and Linneman (1966). Thus, the gravity equation derived can be expressed as:

$$
\mathrm{X}_{\mathrm{ij}}=K \frac{\mathrm{Y}_{\mathrm{i}}^{\beta_{1}} \mathrm{Y}_{j}^{\beta_{2}}}{\mathrm{D}_{i j}^{\beta_{3}}}
$$

Where $\mathrm{X}_{\mathrm{ij}}$ denotes the value of exports between countries $i$ and $j, Y_{i}$ is the economic growth of country $i, Y_{j}$ is the economic growth of countries $j, D_{i j}$ denotes the geographical distance between county $i$ and countries $j, K$ is the constant proportionality and $\beta$ 's are response parameters. For sake of simplicity, equation (1) is often transformed into linear form by using natural logarithm so that it confirms to the usual regression analysis:

$$
\ln X_{i j}=\beta_{0}+\beta_{1} \ln Y_{i}+\beta_{2} \ln Y_{j}+\beta_{3} \ln D_{i j}
$$

where the $\beta$ 's are the coefficients to be estimated. Equation (2) is the baseline model where bilateral trade flows are expected to be a positive function of incomes and negative function of distance. However, because of the existence of huge amount of variations in trade that cannot be explained by the traditional variables, the basic gravity model has later been augmented with many choice variables.

Generally, classical gravity model uses cross-section data to estimate trade effects and trade relationship for a particular time period. In reality, however, cross-section 
data observed over several time periods (panel data) result in more useful information than cross-section data alone. The advantage of gravity model was that, first, panel can capture the relevant relationships among variables over time; and second, panel can examine unobservable tradingpartners' individual effect (Roy and Rayhan, 2012). Egger (2000) argues that panel data methods are the most proper for separating time-invariant and country specific effects.

\section{The Fixed Effect Model (FEM)}

In the formulation of the fixed effect model the intercept in the regression is allowed to differ among individual units in recognition of the fact that each crosssectional unit might have some special characteristics of its own. That is, the model assumes that differences across units can be captured in differences in the constant term. The $I$ a are random variables that capture unobserved heterogeneity. The model allows each cross-sectional unit to have a different intercept term though all slopes are the same, so that

$$
y_{i t}=x_{i t} \beta+\alpha_{i}+\varepsilon_{i t} \quad \mathrm{i}=1,2, . ., \mathrm{N} \mathrm{t}=1,2, . . \mathrm{T}
$$

where $\varepsilon_{i t}$ is iid over $i$ and $t$.

The subscript $i$ to the intercept term suggests that the intercepts across the individuals are different, but that each individual intercept does not vary over time. The FEM is appropriate in situations where the individual specific effect might be correlated with one or more regressors (Gujarati, 2003).

\section{Random Effect Model (REM)}

In contrast to the FEM, the REM assumes that the unobserved individual effect is a randomly draw from a much larger population with a constant mean (Gujarati, 2003). The individual intercept is then expressed as a deviation from this constant mean value. The REM has an advantage over the FEM in that it is economical in terms of degrees of freedom, since we do not have to estimate $\mathrm{N}$ cross-sectional intercepts. The REM is appropriate in situations where the random intercept of each cross- sectional unit is uncorrelated with the regressors. The basic idea is to start with Equation (3). However, instead of treating $\beta_{1 \mathrm{i}}$ as fixed, it is assumed to be a random variable with a mean value of $\beta_{1}$. Then the value of the intercept for individual entity can be expressed as:

$$
\alpha_{i}=\alpha+u_{i t} \quad \text { where } \mathrm{i}=1,2, \ldots \ldots, \mathrm{n}
$$

The random error term is assumed to be distributed with a zero mean and constant variance:

Substituting (4) into (3), the model can be written as:

$$
\begin{aligned}
& y_{i t}=x_{i t}^{\prime} \beta+\alpha+u_{i t}+\varepsilon_{i t} \\
& y_{i t}=x_{i t}^{\prime} \beta+\alpha+\omega_{i t}
\end{aligned}
$$

The composite error term $\omega_{i t}$ consists of two components: $u_{i t}$ is the cross-sectional or individualspecific error component, and $\varepsilon_{i t}$ is the combined time series and cross-sectional error component, given that

$$
u_{i} \sim\left(0, \sigma_{u}^{2}\right), \varepsilon_{i} \sim\left(0, \sigma_{\varepsilon}^{2}\right)
$$

Where $\varepsilon_{i t}$ is independent of the $\mathrm{X}_{\mathrm{it}}$ (Gujarati, 2003).

Generally, the FEM is held to be a robust method of estimating gravity equations, but it has the disadvantage of not being able to evaluate time-invariant effects, which are sometimes as important as time-varying effects. Therefore, for the panel projection of potential bilateral trade, researchers have often concentrated on the REM, which requires that the explanatory variables be independent of $u_{i t}$ and $\varepsilon_{i t}$ for all cross-sections ( $\mathrm{i}, \mathrm{j}$ ) and all time periods (Egger, 2002). If the intention is to estimate the impact of both time-variant and invariant variables in trade potential across different countries, then the REM is preferable to the FEM (Ozdeser, 2010).

\section{Model Specification}

The study was adopted and used the econometric specification of the dynamic panel gravity model specified as equation (6).

$$
\begin{aligned}
\ln E S E_{i j t} & =\beta_{0}+\beta_{1} \ln G D P_{i t}+\beta_{2} \ln G D P_{j t}+\beta_{3} \ln P O P_{i t}+\beta_{4} \ln P O P_{j t} \\
& +\beta_{5} \ln R E R_{i j t}+\beta_{6} \ln I N F_{i t}+\beta_{7} \ln D I S_{i j t}+\alpha_{i}+\varepsilon_{i j t}
\end{aligned}
$$

From Equation (6), ESE $\mathrm{ijt}_{\mathrm{jt}}$ is Ethiopia's Sesame Export at time $t, G D P_{i t}$ is real GDP of the exporting country (Ethiopia) at time $t, G D P_{j t}$ is real GDP of the importing country at time $t, \mathrm{POP}_{\mathrm{it}}$ is the population of exporting country at time $t, \mathrm{POP}_{\mathrm{jt}}$ is the population of importing country at time $t, R R_{i j t}$ is the real exchange rate between countries $i$ and $j$ at time $t, I N F_{i t}$ is domestic inflation of exporting country at time $\mathrm{t}$ and $\mathrm{DIS}_{\mathrm{ijt}}$ is the time invariant physical distance between economic centre of exporting and importing country. Below is an explanation of how each of the above factors was theoretically expected to affect Ethiopia's sesame exports.

GDP is a measure of the size of a country's economy, as a result countries with higher GDP are assumed to trade more than countries with lower GDP. It captures the productive capacity of the exporting country and the purchasing power of the importing country. The higher GDP of the importing country implies greater demand for imports and the higher GDP of exporting country implies greater supply for exports (in our case Ethiopia's sesame exports). Hence, the coefficients of GDPs were expected to be positive.

The coefficient of the population is used to measure the influence Ethiopia's sesame export and that of Ethiopia's sesame importers degree of self-sufficiency and absorption effect. Ethiopia with large population size was expected to produce and export more due to economies of scale resulting from cheap labor. Conversely, it can also export less due to higher domestic absorption effect of larger population size. Thus, the coefficient of Ethiopia's population can be positive or negative. On other direction, Ethiopia's sesame importers with large population size are 
indicative of the potentially larger market size and are expected to import more. So, the coefficient of the Ethiopia's sesame importers population was expected to be positive.

Real exchange rate is incorporated as a measure for the relative price of foreign goods in terms of domestic goods. Exchange rate movements affect a nation's trading relationships with other nations. Currency appreciation makes a country's exports more expensive in foreign markets, while currency depreciation makes a country's exports cheaper in foreign markets. With a higher price, we would expect to see a fall in the quantity of exports. Thus, the coefficient of the real exchange rate was expected to be negative, implying that an appreciation of the real exchange rate discourages exports.

The inflation is price rises that lower the productivity, raise the land cost and also inflation represents a rise in the domestic price of goods and services and beyond any increase in productivity. Therefore, the coefficient domestic inflation was expected to be negative. The weighted distance is indicative of the degree of trade resistance or the ability to stay in the trade process with the given transportation cost between the trade partners. The higher the distance, the higher the transportation costs and hence the coefficient was expected to be negative.

\section{Panel Unit Root Test: Lavin-Lin-Chu (LLC) Test}

Levin, Lin, and Chu (2002) propose a test which had an alternative hypothesis that the expected values were identical and negative. Because expected value was fixed across individual, this was one of the most complicated of the tests because the data from the different individuals need to be combined into a single final regression. This panel unit root tests derived a unit-root test for a short panel that assumes the time dimension, T, is fixed or short. LLC test assumed that is independent and identically distributed with constant variance across panels. Because of the bias induced by the inclusion of the panel means in this model, the expected value of the estimator was not equal to zero under the null hypothesis. Notice that, the LLC test assumes that all panels share the same autoregressive parameter.

\section{Result and Discussion}

\section{Panel Unit Root Test}

Before estimating the panel Gravity model, the study analyzed the univariate characteristics of the data which requires panel unit root tests. Unit root test was the first step in determining a potentially co integrated relationship between the variables. If all variables were stationary, then the traditional estimation methods preserved to estimate the relationship between the variables. If the variables were nonstationary, a test for co integration was required. Levin, Lin and Chu (2002) panel unit root tests were applied. From Table 1 it could be observed that all variables were stationary at level except domestic inflation which was stationary at first difference. Therefore, all variables had no panel unit root since all p-values were less than 5\% level of significance

Table 1 Panel Unit Root test: Levin-Lin-Chu Test

\begin{tabular}{l|ccc}
\hline \multicolumn{1}{c}{ Variables } & \multicolumn{3}{c}{ Levin-Lin-Chu Test } \\
\cline { 2 - 3 } & Level & Difference & P-Value \\
\hline Ethiopia's Sesame Export & -3.0187 & - & 0.0013 \\
Ethiopia's GDP & -3.6606 & - & 0.0001 \\
Partner's GDP & -5.9840 & - & 0.0000 \\
Ethiopia's Population & -2.3341 & - & 0.0098 \\
Partner's Population & -4.1576 & - & 0.0000 \\
Real Exchange Rate & -2.2591 & - & 0.0119 \\
Weighted Distance & -3.6606 & - & 0.0001 \\
Domestic Inflation & - & -2.4877 & 0.0064 \\
\hline
\end{tabular}

Source: (Own computation, 2019)

\section{Panel Data Model Estimation}

The estimation results of equation (6) were presented in Table (2), where the equation (6) was estimated by two alternative models, fixed effects and random effects model. Furthermore, the table showed that the results of Hausman test which used to determine the more appropriate model. The study performed Hausman test to compare the estimations of the fixed and random effects model, based on this test the random effects model was a more appropriate model.

The estimation result of the panel gravity model of Ethiopia's sesame export performance was estimated by random effect model approach and presented in Table 1.

Table 1 revealed that Ethiopia's sesame exports performance was found to be statistically significantly and positively influenced by real gross domestic product of Ethiopia and the importing countries. But the real exchange rate and weighted distance were found to have a statistically significant negative effect on sesame export performance of Ethiopia. Finally, the remaining three explanatory variables: the population of the exporting countries (Ethiopia), population of importing countries and domestic inflation were found to be insignificant at $5 \%$ level of significance.

The coefficient of real gross product of importing countries was found to be statistically significant at 5\% level. The positive value was consistent with the theoretical expectation of gravity trade that expects that trade capacity increase with an increase in a partner's economic size. The estimated coefficient of 1.63 of the real gross domestic product of importing countries suggests that a $1 \%$ increase in real gross domestic product of importing countries was result in nearly a $1.63 \%$ increase in the flows of Ethiopia's 
sesame exports. Importing countries with larger gross domestic product indicates higher demand for Ethiopian sesame. This finding was reliable with the (Henry and Wilfred, 2015) that using the gravity model, the study discovered that the real GDP of importing countries had a positive effect on the value of bilateral trade between considered in the study for the years 1980-2012.

On the other side, the estimated coefficient of Ethiopia's real gross domestic product was 7.12 which implied that keeping other variables constant, a $1 \%$ increase in Ethiopia's real gross domestic product was result in roughly $7.12 \%$ increase in Ethiopia's sesame exports. Supply side real gross domestic product improvement was an indication for better production power. The result was in conformity with the study on African countries used a dynamic panel data set for 48 African countries over the period 1987-2006 to identify the key determinants of export performance and found that supply capacity had a positive effect on the export performance (Mold et al, 2008).

The real exchange rate was found to be statistically significant at 5\% level. The result was consistent with the theoretical expected negative sign in that the level of export decreases as relative price of foreign goods in terms of domestic goods was increases. The estimated coefficient of real exchange rate was -1.42 which imply the country's export declined by $1.42 \%$ as currency exchange rate was increase by $1 \%$. The result was consistent with the (Negussie and Dessalegn, 2014) that investigated Determinants of Bilateral Trade between Ethiopia and Its Major Trading Partners': A Gravity Model Approach for the period of 10 years (2000-2009) and they found that bilateral real exchange rate had a negative impact on Ethiopia's total export performance.

The variable weighted distance was found to be statistically significant at $1 \%$ level. The result was also consistent with the theoretical expected negative sign in that the level of export declines as the distance between Ethiopia and its trading partners increases. The estimated coefficient of weighted distance was -3.59 which imply that the county's imports declined by $3.59 \%$ as the distance between Ethiopia and the importing county increases by $1 \%$. The result was consistent with the (Yishak, 2009) that investigated determinants export performance of Ethiopia using panel gravity model approach in the period 19952007 consisting 30 major trade partners and he found that transportation cost had a negative impact on Ethiopia's export performance.

Finally, the results of the random effects model indicated that $0.435(43.5 \%)$ of the variations in Ethiopia's sesame export performance can be explained by the independent variable that employed in this study based on the value of $\mathrm{R}^{2}$. From the overall results of F-statistics, all explanatory variables were jointly affecting the response variable.

\section{Model Diagnosis Tests}

Autocorrelation Lagrangian Multiplier (LM) Test

Serial correlation/autocorrelation was the violation of assumption stating the error term was uncorrelated with each other. When serial correlation exists, it causes the estimated variances of the regression coefficients to be biased and this leads to unreliable hypothesis testing. In addition in a presence of serial correlation, the t-statistics should actually appear be more significant than they really it should be. There were various tests exist to check whether there exists serial correlation. However, in this study, Wooldridge test for autocorrelation was applied.

As observed from table 3, it showed that failed to reject the null hypothesis and conclude the data did not have firstorder autocorrelation.

\section{Testing for cross-sectional dependence}

It was important to use Pasaron CD test of crosssectional dependence to test whether the residuals were correlated across entities. Null hypothesis: there was no serial correlations and Alternative hypothesis: there is serial correlation.

Table 2. Estimation results

\begin{tabular}{l|cc}
\hline \multicolumn{1}{c|}{ Variables } & Fixed Effect & Random Effect \\
\hline Ethiopia's GDP & -1.101001 & $7.124^{* *}$ \\
Partners GDP & $3.706552^{* *}$ & $1.628^{* *}$ \\
Ethiopia's Population & 15.74044 & 10.59 \\
Partners Population & $-3.407018^{* *}$ & -0.545 \\
Real Exchange Rate & $-1.162423^{* *}$ & $-1.386^{* *}$ \\
Domestic Inflation & -0.0126742 & -0.011 \\
Weighted Distance & & $-3.592^{* *}$ \\
Constant & -73.12441 & -148.49 \\
R $^{2}$ & 0.342 & 0.435 \\
F- statistics & & 31.63 \\
Hausmen test & & $6.23^{*}$ \\
\hline
\end{tabular}

Source: (Own computation, 2019) Note that $*$ significant at $1 \%$, ** significant at 5\%

Table 3. Autocorrelation Lagrangian Multiplier (LM) Test

Wooldridge test for autocorrelation in panel data

H0: no first-order autocorrelation

$\mathrm{F}(1,6)=0.214$

Prob $>\mathrm{F}=0.6603$

Source: (Own computation, 2019) 
Table 4. Pesaran's CD test of cross sectional independence

Pesaran's test of cross sectional independence $=1.230, \operatorname{Pr}=0.2479$

Average absolute value of the off-diagonal elements $=0.2187$

Source: (own calculated result, 2019)

Table 5. Skewness and Kurtosis tests for Normality

\begin{tabular}{l|ccccc}
\hline \multicolumn{1}{c|}{ Variables } & Obs & Skewuness & Kurtosis & adj chi ${ }^{2}(2)$ & Prob>chi $^{2}$ \\
\hline Ethiopian Sesame Export & 143 & 0.5614 & 0.3595 & 1.19 & 0.5503 \\
Ethiopia's GDP & 143 & 0.8271 & 0.0000 & 6.36 & 0.0603 \\
Partners GDP & 143 & 0.8054 & 0.0984 & 2.84 & 0.2416 \\
Ethiopia's Population & 143 & 0.8490 & 0.0000 & 2.78 & 0.0612 \\
Partners Population & 143 & 0.0000 & 0.7101 & 4.39 & 0.2148 \\
Real Exchange Rate & 143 & 0.1624 & 0.8112 & 5.96 & 0.3258 \\
Domestic Inflation & 143 & 0.0000 & 0.0104 & 2.00 & 0.0956 \\
Weighted Distance & 143 & 0.2890 & 0.0237 & 6.00 & 0.0699 \\
\hline
\end{tabular}

Source: (Own computation, 2019)

As illustrated from table 4 the null hypothesis of no serial correlation was not rejected that implies the variables were not correlated with the disturbance terms.

Testing Normality estimation Results

Normality tests were used to determine if a data set was well-modeled by a normal distribution and to compute how likely it was for a random variable underlying the data set to be normally distributed. The test for normality of the residual was performed with the aid of numerical methods in which skewness/kurtosis test was used.

As observed from Table 4 the skewness test showed that the model disturbances were normally distributed at 5 percent significance level. The Kurtosis test showed that the disturbances of the models were probably normally distributed at $5 \%$ level.

\section{Conclusion and Recommendation}

The objective of this study was to identifying the major determinant factors of the supply-side and demand-side factors of the Ethiopia's sesame export performance. To deal with this gap it used panel data containing the 11 Ethiopia's sesame importers in the period through 2002 up to 2014. This study was used yearly data extracted from the databases of FAO Statistics, IMF, WB and WDI. Variable Ethiopia's sesame exports was used as dependent variable and the variables weighted distance, real exchange rate, domestic inflation and both demand-and supply-side of the variables: gross domestic product and population were used as the explanatory variable.

Considering empirical output of this study, the results explained that the Ethiopia's sesame exports performance to the importing countries mainly depends on real gross domestic product of importing countries, weighted distance between Ethiopia and its importing countries and real exchange rate were statistically significant. These variables were found to be negatively associated with Ethiopia's sesame exports performance except that the variable real gross domestic product of importing countries had positively related while the variable population of both importing countries and Ethiopia, real gross product of Ethiopia, and the domestic inflation were found to be statistically insignificant.
The researchers recommends that its important for policy maker should be focus on the policies that ensure low transaction costs through promoting trade within the region since the distance play a negative role in determining the value of Ethiopia's sesame exports performance. Also, the policy maker should be adopted the policies that reduce the cost of shipping through improving the infrastructure for shipments sector and contract a free trade agreement with distant countries.

Additionally, since there is a positive impact of Ethiopian real gross domestic product on sesame exports performance, the policy maker must be undertake the policies that promote their economic growth. Finally, based on the data of sesame exports, the Ethiopian exports should focus in some commodities and for some destinations. Therefore, the government should encourage the private sector to diversify their products and improving the quality of its products to increase the competitiveness of Ethiopian products in foreign markets.

\section{References}

Agricultural Transformation Agency (ATA). 2017. Agricultural Commercialization in Ethiopia: A Review of Warehouse Receipts in the Maize, Wheat, Sorghum and Tef Value Chains.

Baltagi B. 2005. Econometric Analysis of Panel Data. Third edition. Wiley.

Egger P. 2000.A Note on the Proper Econometric Specification of the Gravity Equation, Economics Letters, 66, pp. 2531.http://dx.doi.org/10.1016/S0165-1765(99)00183-4.

Egger P. 2002. An Econometric View on the Estimation of Gravity Models and the Calculation of Trade Potentials. World Economy, 25, 297-312.http://dx.doi.org/10.1111 /1467-9701.00432.

Ethiopian Revenues and Customs Authority (ERCA). 2017. Annual Report. Retrieved from: http://www.erca.gov.et/.

Eyayu T. 2014. Determinants of agricultural export in SubSaharan Africa: evidence from panel study. American Journal of Trade and Policy, 1(3).

Food and Agriculture Organization.2014. World Statistical Compendium for Raw Hides and Skins, Leather and Leather Footwear 1998-2014, Rome.

Gujarati ND. 2003. Basic Econometrics. 4th Edition, Tata McGraw-Hill, New Delhi, 748, 807. 
Henry T, Wilfred N. 2015. Determinants of Uganda's Export Performance: A Gravity Model Analysis.International Journal of Business and Economics Research 4(2): 45-54, https://doi: 10.11648/j.ijber.20150402.14.

Levin A, Lin CF, Chu CSJ. 2002. Unit-Root Test in Panel Data: Asymptotic and Finite Sample Properties. Journal of Econometrics, 108, 1-24. https://doi.org/10.1016/S03044076(01)00098-7.

Linder S. 1961. An essay on trade and transformation. New York: Wiley.

Linnemann H. 1966. An Econometric Study of International Trade Flows. Holland Publishing, Amsterdam. https://doi.org/10.2307/2229319.

Mili Roy, IsratRayhan. 2012. Import Flows of Bangladesh: Gravity Model Approach under Panel Data Methodology. The Dhaka University Journal of Science, 60(2):153157.https://doi.org/10.3329/dujs.v60i2.11485.

Mold A, Paulo S, Prizzon A. 2008. Taking stock of the credit crunch-implications for development finance and global governance. OECD Development Centre working paper No. 277. https://doi.org/10.1787/224377364587.

Naoh A. 2018.Determinates of Agricultural Export Trade: A Case of Sesame Export from Ethiopia. http://localhost:80 /xmlui/handle/123456789/13573.

National Bank of Ethiopia (NBE). 2017. Annual Report 2016/17. Addis Ababa.

Negussie Z, Dessalegn G. 2014.Determinants of Bilateral Trade between Ethiopia and Its Major Trading Partners: A Gravity Model Approach. Journal of Economics and Sustainable Development 5(15).
Newton I. 1687. Philosophies Naturalis Principia Mathematica. Retrieved 14 July 2014 from University of CambridgeCambridge Digital Library. Retrieved from. http://cudl.lib.cam.ac.uk/view/PR-ADV-B.

Orindi MN. 2011. Determinants of Kenya's exports: a gravity model approach. Int J Econ Political Integr 1(1):3-14.

Ozdeser H, Ertac D. 2010. Turkey's Trade Potential with Euro Zone Countries: A Gravity Study. European Journal of Scientific Research, 43, 15-23.

Tinbergen J. 1962. Shaping the World Economy: Suggestions for an International Economic Policy. New York: The Twentieth Century Fund.

UNCTAD. 2017. The State of Commodity Dependence 2016. New York and Geneva.

UNCTAD. 2008. Export competitiveness and development in LDCs: policies, issues and priorities for LDCs for Action during and Beyond UNCTAD XII, UNCTAD/ALDC/2008.

Wondesen T, Fekadu G. 2019.A Dynamic Panel Gravity Model Application on the Determinant Factors of Ethiopia's Coffee Export Performance. Annals of Data Sciencehttps://doi.org /10.1007/s40745-019-00198-4.

World Bank. 2014. Third Ethiopia Economic Update: Strengthening Export Performance through Improved Competitiveness. Washington, DC. (C) World Bank. https://openknowledge.worldbank.org/handle/10986/20026 License: CC BY 3.0 IGO.

Yishak T. 2009. Determinants of Ethiopia's export performance: A gravity model analysis. Trade and development discussion paper No. 01/2009, BKP Development Research and Consulting, Germany. 